\title{
The Manufacturing Sector Impact of Monetary Policy Frameworks: Evidence from Nigeria
}

\author{
http://doi.org/10.21272/fmir.5(3).14-22.2021
}

Oludayo Elijah Adekunle, ORCID: https://orcid.org/0000-0002-5870-9384

Department of Banking and Finance, Adekunle Ajasin University Akungba-Akoko, Ondo State, Nigeria

\begin{abstract}
Monetary policy as macroeconomic tool is germane to maintain economic balances and stimulate sectoral growth. However, the channels through monetary policy influenced manufacturing sector has not been adequately explored in Nigeria. Therefore, this study was carried out to uncover the linkage between monetary policy channels and manufacturing sector output in Nigeria within the period of 1986 to 2018. The unit root result based on Augmented Dickey-Fuller and Phillips-Peron tests showed the data series are integration of level and first difference. Data were analyzed with Autoregressive Distributed Lag-Bound Co-integration dynamic technique. It was discovered from the study that, monetary policy channels determines manufacturing sector output in the long run. It was further established that, manufacturing sector output responded positively and significantly to momentary policy rate, broad money supply and inflation rate while cash reserve ratio and exchange rate had negative and insignificant relationship with manufacturing sector output in the long run coefficients with mixed effects in the short run coefficients. These results suggest that, monetary policy channels are powerful tool for influencing manufacturing sector output and promoting sectroal growth especially in the long run. Thus, it was suggested that the current monetary policy frameworks should be maintained and sustained, while cash reserve ratio of banks should be reviewed to support lending to the manufacturing sector. The growth of money supply should be adequately monitored and controlled in line with the structure of the economy. Finally, appropriate and stable macroeconomic policies should be initiated to ensure macroeconomic stability capable of supporting manufacturing sector activities.
\end{abstract}

Keywords: Monetary policy, manufacturing sector, co-integration, ARDL.

JEL Classification: E52, O14, B23.

Cite as: Adekunle, O.E. (2021). The Manufacturing Sector Impact of Monetary Policy Frameworks: Evidence from Nigeria. Financial Markets, Institutions and Risks, 5(3), 14-22. http://doi.org/10.21272/fmir.5(3).14$\underline{22.2021}$

Received: 19 , July, 2021

Accepted: 16, August, 2021

Published: 13, September, 2021

Copyright: (C) 2021 by the author. Licensee Sumy State University, Ukraine. This article is an open access article distributed under the terms and conditions of the Creative Commons Attribution (CC BY) license (https://creativecommons.org/licenses/by/4.0/)

\section{Introduction}

Achieving sustainable growth and development remain one of the major focus of governments globally. Government mainly stimulate the development of real sector of the economy because, this sector can contributes significantly to economic growth through different macroeconomic policies. Monetary policy as a macroeconomic framework is employed by the monetary authority to control and regulate level of economic activities. It is a macroeconomic policy used to control and regulate the level of economic activities (Epstein, 2007; Wulandari, 2012 Osinowo, 2015; Nguyen, 2020). According to Vizek (2006); Ezeaku, Ibe, Modebe, Ugwuanyi and Agbaeze (2018), monetary policy is used to control the cost, value, quantity and availability of credit to achieve macroeconomic objectives of price stability, employment creation and output growth.

One of the major sectors in which monetary policy is being used to stimulate, is the manufacturing sector. The manufacturing sector is an important sector in a modern economy and has long been recognized as the tool of industrialization. The sector has the capacity to transform the economy through the utilization of economic resources to generate income and wealth. Simbo, Iwuji and Bagshaw (2012); Adekunle (2019) thus averred that, the manufacturing sector serves as the driver of growth and mechanism of economic transformation in countries like China, India, Malaysia, North Korea, Germany, Asian Tigers, South Africa, and Singapore. 
Globally, concerted efforts have been made to revamp the manufacturing sector through technological innovation, stable macroeconomic environment and viable financial system that can support the growth aspiration of the sector. However, effective macroeconomic policy is needed to achieve industrialization of the manufacturing sector. Ganley and Salmon (1997). Leith, Moldovan and Rossi (2015); Abille and Mpuure (2020) stated, that through monetary policy, monetary authority control the allocation of credit and regulate interest rate to stimulate investment in the manufacturing sector. The efforts of monetary authority can be directed through exchange rate, credit and interest rate channel to influence investments in the manufacturing sector (Arnold, Kool, \& Raabe, 2006; Hauptmeier, Holm-Hadulla \& Nikalexi, 2020).

In Nigeria, increasing the productivity of the manufacturing sector remains an important focus of government in the recent years. This is because the sector is perceived to be a leading non-oil sector capable of diversifying the economy and creating much needed contributions through employment creation, income distribution, poverty alleviation and export promotion in the economy. Thus, Imoughele and Ismaila (2014); Shobande (2019) opined that, in order to position the Nigeria manufacturing sector for the purpose of leading economic transformation, monetary authority have formulated diver monetary policy through different monetary channels to ensure that the manufacturing sector operate optimally in the economy. The monetary authority has tried to ensure the stability of exchange rate, price level and other macroeconomic variables which could influence the operation of the manufacturing sector.

In spite of these policy thrusts, the government and other stakeholders are worried about the underwhelming performance of the manufacturing sector when compared to other economy like China (Imoughele \& Ismaila, 2014; Igoni, Onwumere \& Orlu, 2020). Available statistic shows that, contributions of the manufacturing to economic growth have been fluctuating over time. Manufacturing output to gross domestic product from $8.75 \%$ in 2004 to $7.99 \%$ in $2005,7.27 \%$ in 2006 before rising slightly to $7.28 \%$ in 2007 . However, the sector's contribution to GPD fell to $7.05 \%$ in 2008 and rose to $7.16 \%$ in 2009 before falling to $6.55 \%$ in 2010 . The sector recorded improved trends from 2011 to 2015 with sector's contributing to GDP rising to $7.19 \%$ in 2011 , $7.79 \%$ in 2012, 9.03\% in 2013 and $9.75 \%$ in 2014. However, there was relapse in the manufacturing sector contribution to GDP from $9.75 \%$ in 2014 to $9.53 \%, 8.77 \%$ and $8.83 \%$ in 2015,2016 and 2017 before rising slightly to $9.7 \%$ in 2018 (Central Bank of Nigeria, 2018). These fluctuating trends have raise a question on the effectiveness of monetary policy in stimulating sectoral performance in Nigeria.

Quite a number of studies have been conducted on the effect of monetary policy in Nigeria. However, few of these studies examined the effect of monetary policy on manufacturing sector without considering the monetary policy channel in their empirical model. Broad money supply was employed in previous studies without adopting the combination of monetary policy rate and cash reserve ratio alongside exchange rate as important channel of monetary policy for proper empirical analysis and policy frameworks. In light of the above gap and the recent efforts of the government to reposition the manufacturing sector as a tool of sustainable growth and development, this paper examined the effect of monetary policy frameworks on manufacturing sector in Nigeria. The paper is structured into introduction, literature review, data and method, findings, discussion and conclusion.

\section{Literature Review}

Monetary policy as a stabilization tool plays important role in improving sectoral and overall economic performance. Monetary policy stance through expansionary or contractionary frameworks are initiated through different channels like exchange rate and lending channel are adopted to control level of economic activities in different sectors (Borio, Drehmann \& Tsatsaronis, 2011; Besimi, Pugh \& Adnett, 2006; 2011; Bernhard, 2013; Abdul, 2019). Theoretically, Keynes (1936) stated that, monetary policy stimulates economic and sectoral activities through increase in money supply. Also, Matheson (1980) and Levine (1997) asserted sectoral and overall economic growth is determined by variation in stock of money through monetary policy. McCallum (2008) stated that, through the adoption of monetary policy instruments, the central bank influence money supply at constant growth rate to achieve sectoral performance. 


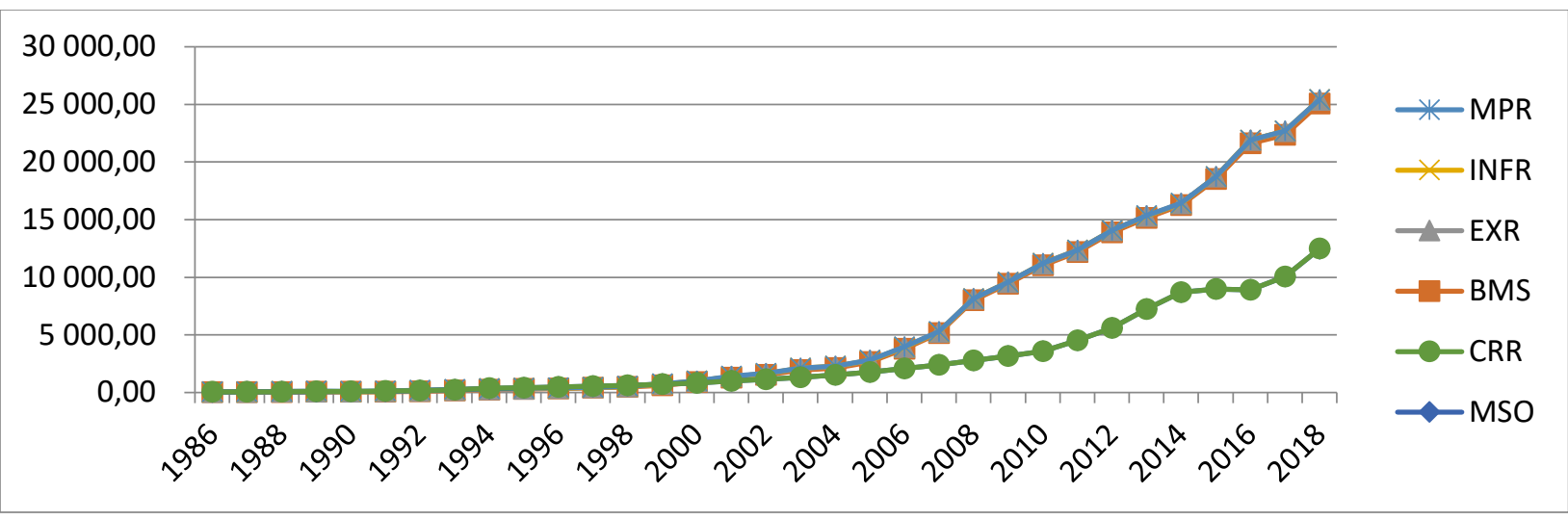

Figure 1: Trends of manufacturing sector output and monetary policy in Nigeria

Source: Central Bank of Nigeria Statistical Bulletin (2008).

MSO = Manufacturing Sector Output, MPR = Monetary Policy Rate, CRR = Cash Reserve Ratio, LBMS = Broad Money Supply, LEXR= Exchange Rate, INFR = Inflation Rate.

Mansor and Ruzita (2005) adopted VAR system on quarterly data from 1971:Q1 to 1999:Q4 to investigate the dynamic responses of manufacturing output to exchange rate and monetary policy shocks in Malaysia. Manufacturing output was revealed to respond robustly to interest rate and exchange rate shocks. Saygin and Evren (2010) evaluated the impact of monetary policy on manufacturing industry in Turkey. It was found that manufacturing sectors responded to contractionary monetary policy shock through output reduction. Vizek (2006) investigated monetary transmission in Croatia based on granger causality and error correction techniques, monetary policy was found to affects industrial output through changes in the exchange rate and money supply. Tahir (2012) studied the monetary transmission channels for Brazil, Chile and Korea base on Structural Vector Autoregression (SVAR) approach and it was found exchange rate and share price channels are more powerful in determining output level.

In Nigeria, the study of Charles-Anyaogu (2012) conducted between 1980 and 2009 showed that money supply positively influenced manufacturing sector performance. Owolabi and Adegbite (2014); Imoughele and Ismaila (2014); Okonkwo, Egbulonu and Emerenini (2015); Osakwe, Ibenta and Ezeabasili (2019); Shobande (2019) through the adoption of error correction model also discovered positive relationship between monetary policy and manufacturing sector in Nigeria. Omolade and Ngalawa (2016) based on quarterly data from 1980Q1 to 2010Q found that manufacturing sector did not responded monetary policy shock in Algeria. In line with this, Ezeaku et al., (2018) while analyzing the effect of monetary policy transmission channels on industry performance in Nigeria through the adoption of error correction model found that monetary policy negatively influence industry performance.

\section{Data and Method}

This research was based on ex post facto research design to establish the relationship between monetary policy and manufacturing sector performance Nigeria. The ex post facto research design is considered appropriate because the data for the study are pre-existing data which are not manipulated or controlled. However, the data for the study were time series in nature covering the periods of 1986 and 2018 which were sourced from Central Bank of Nigeria Statistical Bulletin of different issues. Data on manufacturing sector output, monetary policy rate, cash reserve ratio, broad money supply, exchange rate and inflation rate were selected from the empirical studies of Ganley and Salmon (1997); Saygın and Evren (2010); Mansor and Ruzita (2005); Omolade and Ngalawa (2016).

\section{Model Specification}

This research model was built on the Keynes (1936) theory of monetary policy which stated that money matters in the economy and monetary policy are use by the government to control the level of economic activities in the different sectors and overall economy. In Addition, Matheson (1980); Ganley and Salmon (1997); Levine (1997) acknowledged the role of monetary policy in regulating sectoral and economic activities through variation of cost and quantity of money in the economy. According to McCallum (2008), sectoral and overall economic activities and growth can be enhance through the adoption of effective monetary policy via channels such as exchange rate, credit and interest rate. Thus, following this theoretical proposition, this study 
hypnotized that monetary policy and its channels are expected to produce positive effect on manufacturing sector performance. The empirical model for this study is adapted from the model of Vizek, (2006); Mansor and Ruzita (2005); Okonkwo et al., (2015); Ezeaku, et al., (2018) with little modification. Thus, the structural model for this study is given as:

$\mathrm{MSO}=f(\mathrm{MPR}, \mathrm{CRR}, \mathrm{BMS}, \mathrm{EXR}, \mathrm{INFR})$

$\mathrm{LMSO}_{\mathrm{t}}=\beta_{0}+\beta_{1} \mathrm{MPR}+\beta_{2} \mathrm{CRR}+\beta_{3} \mathrm{LBMS}+\mathrm{B}_{4} \mathrm{LEXR}_{\mathrm{t}}+\beta_{5} \mathrm{INFR}_{\mathrm{t}}+\mathrm{e}$

Where: $\mathrm{MSO}=$ Manufacturing Sector Output, MPR $=$ Monetary Policy Rate, $\mathrm{CRR}=$ Cash Reserve Ratio, LBMS $=$ Log of Broad Money Supply, LEXR $=$ Log of Exchange Rate, INFR = Inflation Rate. $\beta=$ Constant Term, $\beta_{1}-\beta_{5}=$ Coefficient of Parameters. e = Error Term.

\section{Model Estimations Techniques}

The data series of the variables employed in this study are expected to be stationary with a mean of zero and constant variance to estimate time series data. Consequently, the time series properties of the data are checked by applying the Augmented Dickey-Fuller test which tested the null hypothesis of non stationary or unit root. The ADF test of stationarity follows the model below:

$\Delta Y_{t}=(p-1) y_{t-1}+\alpha i \sum_{i=1}^{m} \Delta_{y-i}+u_{t}$

The rule is that if the test statistic is greater than the 5 percent critical value, we accept the null hypothesis i.e. the variable is stationary but if the test statistic is less than the 5 percent critical value i.e. the variable is nonstationary, we accept the alternate hypothesis and go ahead to difference once. The outcome of the unit root test showed combination of level, $\mathrm{I}(0)$ and first difference, $\mathrm{I}(1)$ which promoted the adoption of a dynamic techniques by means of Autoregressive Distributed Lag (ARDL) technique. The Autoregressive Distributed Lag (ARDL) require that the variables are either stationary level, first difference or the combination of level or first difference (Pesaran \& Shin, 1991). This technique was considered suitable because the data for the study is small and the technique can easily accommodate small sample size and solve the problem of endogeneity problem. Thus, the co-integration testing between monetary policy and manufacturing sector follows the approach of ARDL Bound test for long run relation given as:

$\Delta \mathrm{LMSO}_{\mathrm{t}}=\alpha_{01}+\beta_{1} \mathrm{MPR}_{\mathrm{t}-1}+\beta_{2} \mathrm{CRR}_{\mathrm{t}-1}+\beta_{3} \mathrm{LBMS}_{\mathrm{t}-1}+\beta_{4} \mathrm{LEXR}_{\mathrm{t}-1}+\beta_{5} \mathrm{INFR}_{\mathrm{t}-1}+\sum_{\mathrm{i}=1}^{\mathrm{q}} \alpha 1 \mathrm{MPR}_{\mathrm{t}-1}+\sum_{\mathrm{i}=1}^{\mathrm{q}} \alpha 2 \mathrm{CRR}_{\mathrm{t}-1}+$ $\sum_{\mathrm{i}=1}^{\mathrm{q}} \alpha 3 \mathrm{LBMS}_{\mathrm{t}-1}+\sum_{\mathrm{i}=1}^{\mathrm{q}} \alpha 4 \mathrm{EXR}_{\mathrm{t}-1} \sum_{\mathrm{i}=1}^{\mathrm{q}} \alpha 5 \operatorname{INFR}_{\mathrm{t}-1}+\varepsilon_{1 \mathrm{t}}$

The short run equation for the ARDL approach is given in equation 5:

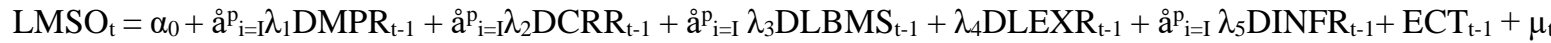

The long run equation for the ARDL approach is given as:

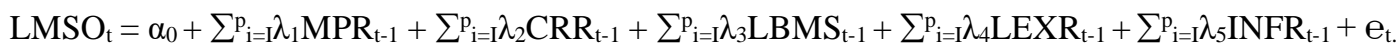

Where: $\mathrm{MSO}=$ Manufacturing Sector Output, MPR $=$ Monetary Policy Rate, $\mathrm{CRR}=$ Cash Reserve Ratio, LBMS $=$ Log of Broad Money Supply, LEXR $=$ Log of Exchange Rate, INFR = Inflation Rate. $\lambda_{1}-\lambda_{6}$ represents the parameters of the variables. $\mathrm{e}=$ Error Term. $\lambda$ is the coefficients relating to the short run dynamics of the convergence to equilibrium, D represents the differencing of the variables, $\mathrm{ECT}_{\tau-1}$ is the error correction term.

\section{Presentation of Results}

\section{Unit Root Test Result}

The data series for this study are tested for stationarity in order to determine their order of integrations and ensures that they do not contain unit root which may invalidate the results. For this purpose, Augmented Dickey-Fuller and Phillips-Peron tests are applied and reported in

Table1. Summary of Unit Root Tests

\begin{tabular}{|l|c|c|c|c|c|}
\hline \multicolumn{3}{|c|}{ Augmented Dickey-Fuller Test } & \multicolumn{3}{c|}{ Phillips-Peron Test } \\
\hline Data Series & t-Statistic & Prob. & t-Statistic & Prob. & Level of Integration \\
\hline LMSO & -4.117551 & 0.0148 & -3.178048 & 0.0314 & $\mathrm{I}(1)$ \\
\hline MPR & -3.746099 & 0.0334 & -3.149707 & 0.0328 & $\mathrm{I}(0)$ \\
\hline
\end{tabular}


Table1 (cont.). Summary of Unit Root Tests

\begin{tabular}{|l|c|c|c|c|c|}
\hline CRR & -7.041200 & 0.0000 & -7.045562 & 0.0000 & $\mathrm{I}(1)$ \\
\hline LBMS & -4.388773 & 0.0078 & -3.579066 & 0.0122 & $\mathrm{I}(1)$ \\
\hline LEXR & -5.830880 & 0.0002 & -5.662129 & 0.0001 & $\mathrm{I}(1)$ \\
\hline INFR & -3.612199 & 0.0001 & -5.672315 & 0.0001 & $\mathrm{I}(1)$ \\
\hline
\end{tabular}

$1(0)=$ Stationary at Level; $1(1)=$ Stationary at First Difference

Source: Researcher's Computation, 2021.

The summary of Augmented Dickey-Fuller and Phillips-Peron tests presented in Table 1 shows that monetary policy rate is stationary at level while log of manufacturing sector output, cash reserve ratio, log of broad money supply, log of exchange rate and inflation rate are free from unit root problem at first difference. This indicates that, monetary policy rate is integrated at level while log of manufacturing sector output, cash reserve ratio, log of broad money supply, log of exchange rate and inflation rate are integrated at first difference. This informs the adoption of autoregressive distributed lag technique as suggested by Pesaran and Shin (1991).

\section{Co-integration Test Result}

The long run relationship between monetary policy and manufacturing sector output is determine using ARDL Bound test. The test is conduced based on lag two as suggested by the Akaike Information Criterion. The cointegration result is shown in Table 2.

Table 2. ARDL Bound Co-integration Test

\begin{tabular}{|l|c|c|}
\hline \multicolumn{1}{|c|}{ Test Statistic } & F-values & Prob. \\
\hline MPR & 210.9253 & 0.0000 \\
\hline CRR & 5.498705 & 0.0300 \\
\hline LBMS & 5.908043 & 0.0251 \\
\hline \multicolumn{3}{|c|}{ Critical Value Bounds } \\
\hline Significance & I0 Bound & 3.79 \\
\hline $5 \%$ & 2.62 & Bound \\
\hline Overall F-value $=4.079156(\mathrm{~K}=5)$ & \\
\hline \multicolumn{2}{|c|}{ Selected Lag According to Akaike Information Criteria =2 $\left(14.27998^{*}\right)$} & \\
\hline
\end{tabular}

Source: Researcher's Computation, 2021.

The result of the long run relationship is presented in Table 2. The result shows that the calculated F-statistic value of 4.079156 is greater than 2.62 lower bound value at 5\% significance level which suggest monetary policy has co-integration relationship with manufacturing sector output. This indicates that monetary policy has the capacity to simulate and cause movement in manufacturing sector output in the long run.

\section{ARDL Coefficients Results}

The ARDL short and long run coefficients results are presented in Table 3 and 4.

Table 3. Short Run Co-integrating Coefficients

\begin{tabular}{|l|c|c|c|c|}
\hline \multicolumn{5}{|c|}{ Dependent Variable: MSO } \\
\hline \multicolumn{1}{|c|}{ Variables } & Coefficient & Std. Error & t-Statistic & Prob. \\
\hline $\mathrm{D}(\mathrm{MPR})$ & 0.013182 & 0.005528 & 2.384831 & 0.0277 \\
\hline $\mathrm{D}(\mathrm{CRR})$ & -0.002655 & 0.003957 & -0.670976 & 0.5103 \\
\hline $\mathrm{D}(\mathrm{CRR}(-1))$ & 0.007620 & 0.003018 & 2.525008 & 0.0206 \\
\hline $\mathrm{D}(\mathrm{LBMS})$ & 0.287507 & 0.123301 & 2.331759 & 0.0309 \\
\hline $\mathrm{D}($ LBMS(-1)) & -0.246975 & 0.160782 & -1.536092 & 0.1410 \\
\hline $\mathrm{D}($ LEXR) & -0.056064 & 0.031100 & -1.802731 & 0.0873 \\
\hline $\mathrm{D}($ INFR) & 0.002712 & 0.000466 & 5.816464 & 0.0000 \\
\hline CointEq(-1) & -0.195130 & 0.053287 & -3.661891 & 0.0017 \\
\hline
\end{tabular}

Source: Researcher's Computation, 2021.

Table 3 presents the result of the short run effects of monetary policy rate, cash reserve ratio, log of broad money supply, $\log$ of exchange rate and inflation on manufacturing sector output. It shows that monetary policy rate has positive and significant effect on log of manufacturing sector output in Nigeria which implies that increase in monetary policy rate. It is revealed that cash reserve ratio has negative and insignificant effect 
on manufacturing sector output in the current period but positive and significant effect on manufacturing sector output at first period lag. Furthermore, the result shows that log of broad money supply has positive and significant effect on log of manufacturing sector output in the current period but negative and insignificant effect on log of manufacturing sector output in Nigeria at lag one. Furthermore, the result of the short run coefficient indicates that there is negative and insignificant relationship between log of exchange rate and log of manufacturing sector output. However, positive and significant relationship is established between inflation rate and log of manufacturing sector output in Nigeria. Finally, the co-integration equation which measures the speed of adjustment in the short run indicates a coefficient of -0.195130 which is significant at $5 \%$. This implies that there is seed of adjustment in the model and any disequilibrium in the short run would be corrected at speed of $19 \%$ towards equilibrium.

Table 4. Long Run Coefficients

\begin{tabular}{|l|c|c|c|c|}
\hline \multicolumn{5}{|c|}{ Dependent Variable: MSO } \\
\hline \multicolumn{1}{|c|}{ Variable } & Coefficient & Std. Error & t-Statistic & Prob. \\
\hline MPR & 0.122317 & 0.041922 & 2.917744 & 0.0088 \\
\hline CRR & -0.038188 & 0.022227 & -1.718112 & 0.1020 \\
\hline LBMS & 1.002629 & 0.123554 & 8.114910 & 0.0000 \\
\hline LEXR & -0.287319 & 0.154970 & -1.854030 & 0.0793 \\
\hline INFR & 0.013899 & 0.004961 & 2.801504 & 0.0114 \\
\hline C & 0.227321 & 0.697375 & 0.325967 & 0.7480 \\
\hline
\end{tabular}

Source: Researcher's Computation, 2021.

The result of the long run is pretested in Table 4. It shows that monetary policy rate has a coefficient of 0.122317 which implies that $1 \%$ increase in monetary policy rate causes $0.12 \%$ increase in $\log$ of manufacturing sector output in Nigeria. This implies that the adoption of expansionary monetary policy and stable monetary which is fixed at $14 \%$ over the years would produce increase in manufacturing sector productivity through increase in lending to the sector. Conversely, the result indicates that cash reserve ratio has negative and insignificant effect on log of manufacturing sector output in Nigeria. This implies that $1.0 \%$ increase in cash reserve ratio will lead to $0.04 \%$ fall in manufacturing sector output as reported in Table 4 . This suggests that increase cash reserve ratio of commercial banks by monetary authority would constraints lending to the manufacturing sector and hence fall in output.

However, it is indicated that there is positive and significant relationship between log of broad money supply and $\log$ of manufacturing sector output with a coefficient of 1.002629 indicating that $1 \%$ increase in money supply in the economy would lead $1.0 \%$ increase in manufacturing sector output. This implies that the adoption of expansionary monetary policy through increase in money supply to stimulate economic activities would lead to increase in manufacturing sector output in the economy. Contrarily, log of exchange rate has negative and insignificant relationship with log of manufacturing sector output in Nigeria with a coefficient of 0.287319 which implies that $1 \%$ increase in exchange rate would lead to fall $0.29 \%$ fall in manufacturing sector output in Nigeria. This indicates unstable and highly depreciated naira exchange rate value would lead to fall in productivity of manufacturing sector through rise in cost of importing foreign materials for manufacturing activities. Finally, inflation rate was found have positive and significant effect on log of manufacturing sector output in Nigeria with coefficient of 0.013899 indicating that $1 \%$ increase inflation rate would lead to $0.01 \%$ increase in manufacturing sector output.

Table 5. Diagnostics Results

\begin{tabular}{|l|c|c|}
\hline \multicolumn{1}{|c|}{ Diagnostics test } & Observed value & P-value (Chi-square) \\
\hline Normality Test (Jarque-Bera) & 1.121997 & 0.5706 \\
\hline Breusch-Godfrey LM test for serial correlation & 3.613065 & 0.1642 \\
\hline Heteroskedasticity Test: Breusch-Pagan-Godfrey & 9.750987 & 0.5529 \\
\hline Ramsey RESET Test & 0.137849 & 0.7148 \\
\hline
\end{tabular}

Source: Researcher's Computation, 2021.

Diagnostics and stability of the residual are reported in Table 5 and it is concluded that residual is normally distributed, has no serial correlation, is Homoscedatic and the model is best fitted and rightly developed. 


\section{Cusum Stability Test}



Figure 2. Stability Test Result

Source: E-views, 9.

The stability test is conducted based on the method proposed by Brown, Dublin and Evans (1975). The result of the Cusum of Squares presented in Figure 2 that the stability line falls the acceptance region of 5\% indicating stability of regression estimate.

\section{Discussion and Conclusion}

Monetary policy serves as potent macroeconomic policy that can be used to either stimulate or correct imbalance depending on the nature of the economy. The policy has the capacity to enhance sectoral activities which informed the investigation on the effects of monetary policy on manufacturing sector output in Nigeria. Therefore, this study adopted times data covering the periods of 1986 to 2018 to determine the linkage between monetary policy and manufacturing sector output in Nigeria. Analysis was conducted using Autoregressive Distributed Lag Bound Co-integration technique and it was discovered that there is long run relationship between monetary policy and manufacturing sector output in Nigeria. The study found and concluded that monetary policy simulate manufacturing sector output in Nigeria which conformed with the theoretical preposition of Keynes (1936) that monetary policy enhance economic activities and overall growth in the economy. The results was also in line with the findings of Mansor and Ruzita (2005); Vizek (2006); Tahir (2012); of Charles-Anyaogu (2012); Osakwe et al., (2019) but contrary with the result of Saygin and Evren (2010); Ezeaku et al., (2018) who established that manufacturing sector output responded negatively to monetary policy. The study recommended that monetary authority through Monetary Policy Committee (MPC) should sustain the current monetary policy frameworks; also, monetary authority through the Central Bank of Nigeria should reduce the reserve requirement of banks in order to increase the funds available for lending to real sector. Finally, money supply should be adequately monitored and controlled in line with the structure of the economy to curb inflationary tendency in the economy.

\section{References}

1. Abdul, S.O. (2019). Interrogating the rationale for monetary and fiscal policies synchronization in Nigeria. Euroeconomica, 38(1), 137-151. [Google Scholar]

2. Abille, A.B. \& Mpuure, D.M. (2020). Effect of monetary policy on economic growth in Ghana. Applied Economics Journal, 27(2), 110-124. [Google Scholar]

3. Adekunle, O.E. (2019). The implication of capital market development on manufacturing sector in Nigeria within the framework of ARDL: Bound testing Approach. Eacta Universitasis Danubius, 15(6), 208-219. [Link]

4. Arnold, I. J. M., Kool, C. J. M., \& Raabe, K. (2006). Industries and the bank lending effects of bank credit demand and monetary policy in Germany. Economic Studies, 48, 1-70. [Google Scholar]

5. Bernhard, O.I. (2013). Monetary transmission mechanism in Nigeria: A causality test. Mediterranean Journal of Social Sciences, 4(13), 377-388. [Google Scholar] 
Financial Markets, Institutions and Risks, Volume 5, Issue 3, 2021 ISSN (online) - 2521-1242 ISSN (print) - 2521-1250

6. Borio, C., Drehmann, M. \& Tsatsaronis, K. (2011). Anchoring countercyclical capital buffers: The role of credit aggregates. International Journal of Central Banking, 7(4), 189-240. [Google Scholar]

7. Brown, R. L., Durbin, J., \& Evans, J. M. (1975). Techniques for testing the constancy of regression relations over time. Journal of Royal Statistical Society, 37(Series B), 149-163. [Google Scholar]

8. Charles-Anyaogu, N.B. (2012). Investigating the performance of monetary policy on manufacturing sector in Nigeria. Arabian Journal of Business and Management Review, 2(1), 12-25. [Link]

9. developing countries: Evidence from a meta-analysis. Emerging Markets Finance and Trade, 56(1), 6884. [CrossRef]

10. Epstein, G. (2007). Central banks, inflation targeting and employment creation. Economic and Labour Market Paper, 2. [Google Scholar]

11. Ezeaku, H.C., Ibe, I.G., Modebe, U.B., Ugwuanyi, N.J. \& Agbaeze, E.K. (2018). monetary policy transmission and industrial sector growth: Empirical evidence from Nigeria. SAGE Open 1-12. [CroosRef]

12. Friedman, M. (1968). The Role of Monetary Policy, American Econometric Review. New York: American Press. [Google Scholar]

13. Ganley, J, \& Salmon, C. (1997). The industrial impact of monetary policy shocks: Some stylized facts. London: Bank of England. [Google Scholar]

14. Gertler M. \& Gilchrist S., (19994). Monetary policy, business cycles, and the behavior of small manufacturing firms. Quarterly Journal of Economics, 109(2), 309-340. [Link]

15. Hauptmeier, S., Holm-Hadulla, F., \& Nikalexi, K. (2020). Monetary policy and regional inequality. Working Paper Series No 2385. [Google Scholar]

16. Igoni, S., Onwumere, J. U. J. \& Orlu, L. (2020). Nexus of monetary policy and per capita income in the Nigerian economy: Is the development sustainable? Journal of Economics and Finance, 11(2), 42-47. [Google Scholar]

17. Imoughele, L.K. \& Ismaila, M. (2014). Empirical investigation of the impact of monetary policy on manufacturing sector performance in Nigeria (1986 - 2012). International Journal of Education and Research, 2(1) 1-20. [Google Scholar]

18. Keynes, J.M. (1936). The general theory of employment, interest and money. London, UK: Palgrave Macmillan. [Link]

19. Leith, C., Moldovan, I., \& Rossi, R. (2015). Monetary and fiscal policy under deep habits. Journal of Economic Dynamics \& Control, 52, 55-74. [Google Scholar]

20. Levine, R. (1997). Financial development and growth: Views and agenda. Journal of Economic Literature, 35, 688-726. [Google Scholar]

21. Mansor, I.H. \& Ruzita, M.A. (2005). Exchange rate, monetary policy and manufacturing output in Malaysia. Journal of Economic Cooperation, 26, 1-28. [Google Scholar]

22. Matheson, D. (1980). Financial reforms and Stabilization Policy in Developed Economies. Development Economics, 7(3), 359-395. [CrossRef]

23. Nguyen, T. M. L. (2020). Output effects of monetary policy in emerging and Developing Countries: Evidence from a Meta-Analysis. Emerging Markets Finance and Trade, 56(1), 68-85. [Link]

24. Okonkwo, O.N., Egbulonu, K.G. \& Emerenini, F.M. (2015). Monetary policy and the manufacturing sector in Nigeria. SSRG International Journal of Economics and Management Studies, 2(1), 11-19. [Google Scholar]

25. Omolade, A. \& Ngalawa, H. (2016). Monetary policy transmission and growth of the manufacturing sector in Algeria. Investment Management and Financial Innovations, 13(4-1), 212-224. [Google Scholar]

26. Osakwe, A., Ibenta, S.N. \& Ezeabasili, V.N. (2019). Monetary policy and the performance of the manufacturing sector in Nigeria (1986-2017). International Journal of Academic Research in Business and Social Sciences, 9(2), 399-413. [CrossRef]

27. Osinowo, O. H. (2015). Effect of fiscal policy on sectoral output growth in Nigeria. Journal of Advances in Economics and Business, 3(6), 195-203. [Google Scholar]

28. Owolabi, A. U \& Adejare, T. A. (2014). Impact of monetary policy on industrial growth in Nigeria. International Journal of Academic Research in Business and Social Sciences, 4(1), 18 - 31. [Google Scholar]

29. Pesaran, M., Shin, Y., \& Smith, R. (2001). Bounds testing approaches to the analysis of level relationships. Journal of Applied Econometrics, 16(3), 289-326. [Google Scholar]

30. Saygin, S \& Evren, E.C. (2010). Understanding sectoral growth cycles and the impact of monetary policy in the Turkish manufacturing industry. Central Bank of the Republic of Turkey, Working papers, 10, 13. [Google Scholar] 
31. Shobande, O. A. (2019). Monetary policy spillovers through industrial growth in Nigeria: A time series analysis. Economics and Business, 33(1), 94-110. [Google Scholar]

32. Simbo, A.B., Iwuji, I.I. \& Bagshaw, K. (2012). The performance of the Nigerian manufacturing sector: a 52-year analysis of growth and retrogression. Asian Economic and Social Society, 2(1), 1-17. [Google Scholar]

33. Tahir, M.N. (2012). Relative importance of monetary transmission channels: A structural investigation; case of Brazil, Chile and Korea. Journal of Economic Literature, 1-42. [Google Scholar]

34. Vizek, M. (2006). Econometric analysis of monetary transmission channels in Croatia. Privrednakretanjaiekonomskapolitika, 109(16), 28-61. [Google Scholar]

35. Wulandari, R. (2012). Do credit channel and interest rate channel play important role in monetary transmission mechanism in Indonesia? A Structural Vector Autoregression Model. Procedia - Social and Behavioral Sciences, 65, 557-563. [Google Scholar] 